\title{
Sustainable development in polyethnic border regions of Ukraine (on the example of Transcarpathia)
}

\author{
Mykhaylo Pityulych ${ }^{1}$, Kateryna Sochka ${ }^{1, *}$, Victoriia Makarovych ${ }^{2}$, Oksana Yoltukhovska ${ }^{2}$, \\ and Nataliya Keretsman ${ }^{3}$ \\ ${ }^{1}$ SHEI "Uzhhorod National University", Finance and Banking Department, 3 Narodna Sq., \\ 88000 Uzhhorod, Ukraine \\ ${ }^{2}$ SHEI "Uzhhorod National University", Department of Accounting and Analysis, 3 Narodna Sq., \\ 88000 Uzhhorod, Ukraine \\ ${ }^{3}$ SHEI "Uzhhorod National University", Department of Economics and Entrepreneurship, 3 Narodna \\ Sq., 88000 Uzhhorod, Ukraine
}

\begin{abstract}
The purpose of this work is to identify some issues of current sustainable development process in polyethnic border regions of Ukraine. The need to involve various domestic stakeholders (like local, regional and national authorities, businesses, households, education and research institutions, NGOs, regional development agencies) and representatives from neighboring countries in elaboration and implementation of sustainable development programs in border regions is substantiated. Conducted survey helped to identify the position of local NGOs representatives, involved into the different regional development projects, about the priority directions of sustainable development and obstacles for their realization in the polyethnic region. Certain peculiarities of sustainable development related to regional polyethnicity have been identified during the survey. Certain ways to increase the involvement of various ethnic groups in process of sustainable development in border regions have been proposed.
\end{abstract}

\section{Introduction}

The idea of sustainable development started to evolve in regional and national strategic planning theory starting from 1980s. Currently, it is focused on balanced progress in economic, social, and environmental areas on local, regional, national and international levels.

The official recognition of sustainable development was identified in the report "Our Common Future" at the UN International Conference on Environment and Development (UNCED) also known as Earth Summit (Rio de Janeiro, Brazil, 1992). Interpretation of sustainable development suggest considering growth in a way that meets the current needs without reducing opportunities for upcoming generations to satisfy their needs $[1, \mathrm{p} .41]$.

\footnotetext{
* Corresponding author: kateryna sochka@yahoo.com
} 
Initially only three directions of sustainable development were identified as economical, social, and environmental sustainability [2].

The study of approaches of foreign and Ukrainian researchers to the interpretation of sustainable development shows strong trend of expanding this concept from simple preservation of natural assets to a more integrated interpretation. This approach involves joint efforts of different governmental and civil society institutions, communities, businesses, and households towards the elaboration and execution of such strategic programs for regional development, which would support the balanced progress of economy and social sphere while keeping environmental norms and preservation of natural resources. Sustainable development is a relatively recent valuable, political and practical approach to elaboration and completion of development strategies in most countries, which anticipates the gradual movement from an economic model of profit maximization to finding a balance between economic, social and environmental components of development.

\section{Objectives of the research}

The purpose of this study is to determine the features of sustainable development in polyethnic border regions of Ukraine and to identify some problematic issues of their development (on the example of the Transcarpathian region of Ukraine).

The Transcarpathian region is a typical example of polyethnic region that has been formed historically. The peculiarity of this region ethnic formation is that its territory during the past centuries has been a part of different countries, namely Austria-Hungary, Czechoslovakia, Hungary, Soviet Union and independent Ukraine. And this process was followed by relevant migration processes. Due to permanent residence of different nationalities for centuries in Transcarpathia, the region is characterized by interethnic tolerance. It should be noted that the majority of the region's population speaks two or three languages and it reflects cultural and linguistic situation and interethnic communications. The region is located along the western borders of Ukraine and borders with $4 \mathrm{EU}$ countries: Poland, Slovakia, Hungary and Romania.

There are subregions and settlements with compact residence of Hungarian, Romanian, Slovak, German ethnic groups in border regions. These nationalities have different cultural, historical, religious and household traditions, and this reflects on the methods of personal farming, entrepreneurship, cuisine, home production of food and wine, blacksmithing, forestry, etc. The neighboring of different nationalities over a long period has led to interactions and enrichment. All the above requires consideration of national diversity in the elaboration and implementation of sustainable development programs at the level of a single community and polyethnic region as a whole.

\section{Background}

The sustainable development idea is a significant theoretical concept that has been strongly enriched in recent decades and is accepted as a guide in elaborating growing strategies on different levels - global, international, national, regional, local (community level) and even institutions.

Noteworthy is the periodization of approaches to progress of theory and practice of sustainable development elaborated by L. Shi, L. Han, F. Yang and L. Gao [3]. Authors proposed to identify three periods in this theory - embryonic (before 1972), molding (1972-1987), and the developing (1987-present) stages [3, p. 3-5]. 
O. Bina [4] suggested to slightly alter the concept of sustainable development and to declare human progress a basis instead of economical growth and consequently, to transform the nature of all directions of this growth into the human beings, society, and planet/nature while economy should be the underlying sum of socioeconomic tradable and nonmarket activities.

According to J. A. Elliott [5] during recent millennium the world is characterized by a huge level of economical, political, social and environmental transformations, therefore the idea of sustainable development should incorporate modern challenges and possibilities of such a globalized world. Therefore, modern sustainable development concept incorporates discussions about the climate change, global economical recession and persistence of poverty that require transformations in behavior of all participants [5, p. 54-55].

A common strategic vision of balanced growth at global level has also developed. The UN approved the report "Our Common Future" in 2015 [6]. There are 17 tasks for sustainable development to transform the world up to 2030 for solving emerging crises in various spheres for different regions. These tasks can be subdivided into four basic pillars economical, social, environmental, and governance.

Understanding of tasks and principles of sustainable development by national governments expanded too. For instance, the UK Government in 1999 defined four basic goals of the sustainable development strategy, namely social progress, effective protection of environment, prudent use of natural assets, maintenance of high and stable rates of economic progress and employment [7, p. 16]. Modern concept of the UK Government sustainable development plan has adopted as the new framework the following principles: living within environmental limits; ensuring strong, healthy and just society; achieving a sustainable economy; promoting good governance; using sound science responsibly [7].

Modern Ukrainian scientists emphasize the importance of ensuring the unity of three directions of sustainable development, in particular, authors [8, p. 10] identify the following key factors that ensure sustainable development: environmental (determines conditions and limits of restoration of ecological systems due to their overuse), economic (formation of economic relations harmonized with the ecological issues) and social (declares human right to a high standard concerning environmental safety and well-being).

Summarizing, the classical interpretation of sustainable development involves ensuring the optimal balance between environmental, social and economic effects of human activity, while sustainable development should be based not on short-term economic results, but on long-term public interests in achieving strategic development goals.

Taking into account current trends in dynamics of global economic, demographic, natural, social and migration processes, scientists also propose to expand the classical approach to the definition of sustainable development.

According to work [9] sustainable development has four interrelated dimensions social (reflects relationship between people, including equality and respect for rights of others), economic (systems that ensure human survival (work and money), environmental (focused on systems that support life on planet), political / institutional (provides democratic governance and decision-making on the use of natural and artificial environment).

In accordance to the national report of Ministry of Economic Development and Trade "Sustainable Development Goals: Ukraine", growth in Ukraine till 2030 should focus on four areas: equitable social development; sustainable economic growth and employment; effective management; ecological balance and development of sustainability [10].

A recent research on possibilities to manage sustainable growing tasks in Ukraine within European green deal demonstrates that national governance efforts should be focused on solving climate changes and protecting ecosystems and biodiversity [11]. 


\section{Material and methods}

Methodological basis of research is scholarly papers of foreign and Ukrainian researchers on sustainable development topic, some national development programs. The empirical part of the article is based on the selected results of survey on the perception of regional NGO leaders about peculiarities and basic directions of sustainable growth in polyechnic regions (on the example of the Transcarpathian region, Ukraine).

Methods applied for collection and interpretation of information are survey, analysis, generalization, synthesis, historical, graphic, and systematic approach.

Paper presents some selected results of survey conducted during the study "Sustainable development in a polyethnic region" (Zakarpattya Regional Center for Socio-Economic and Humanitarian Research, National Academy of Sciences of Ukraine, 2018).

\section{Results and Discussion}

The comprehensive progress of human capital is one of priorities in modern period, therefore it is important to consider polyethnic factor during elaboration of sustainable growth programs. This is especially true in such regions as Transcarpathia, Odesa, Chernivtsi regions, which are characterized by a multinational composition affecting all areas of social and humanitarian policy.

The specific geographical location of region highlights the necessity to cooperate with neighboring countries in joint solution of numerous issues of the balanced growth, like environmental problems related to global climate change. The environmental direction is especially important taking into consideration the spatial position of the region, joint natural resources and other assets with neighboring countries and it can be effectively implemented only in coordination and cooperation with neighboring countries.

The peculiarity of the region is extremely low level of its urbanization, dominance of rural population (63\%), and the negative trends of demographic processes, which creates a number of specific problems for the implementation of sustainable development programs of polyethnic communities in the region [12].

Modern scientists emphasize the increasing importance of the ethnic factor in social development in present conditions, as it affects many processes of social life - regional policy, ethno-national policy, decentralization policy and educational reform, which directly affect the social and economic rights of ethnic minorities. We support the idea of the author [13, p. 275], who emphasizes the necessity to take into consideration the factor of polyethnicity in identifying and implementing different internal and external functions of the government. Due to certain factors (somewhat lower educational and qualification level, low proficiency of state language), ethnic minorities are more vulnerable to negative effects of socio-economic trends in recent years.

Interethnic interaction is manifested in different contacts between ethnic groups, leading to altering of individuals and ethnic groups in general, like:

- Household - borrowing of tools and methods of economic activity, exchange of experience in traditional medicine, cuisine;

- Cultural and educational - exchange of cultural values in the field of education and upbringing of children, traditions;

- Family interaction - establishing and strengthening family relations, interethnic marriages and their consequences;

- Interaction at language level, borrowing words and forming dialects;

- Economic - convergence of certain forms of agricultural production, environmental protection management, tourism, services; 
- Management - borrowing best practices of management, personnel selection and requirements, staff motivation system;

- Religious interaction.

Thus, close interaction of different ethnic groups directly affects the potential of all pillars of regional balanced growth.

Basing on the synthesis of information sources and study of theoretical approaches, we assume that sustainable growth of a polytechnic region should be considered as a system of interconnected long-term measures jointly worked out by different levels of governments, businesses, households, NGOs, including national and cultural organizations, research and educational institutions. All these long-term objectives are reflected in the relevant development strategies of the region. The implementation of these strategies will ensure the improvement of the living standards of population, satisfying spiritual, cultural, educational, religious and other needs of different ethnic groups, creating a favorable conditions for implementing entrepreneurial potential of local communities and attracting investment from outside the region, while simultaneously maintaining or improving natural assets of these regions (Fig. 1).

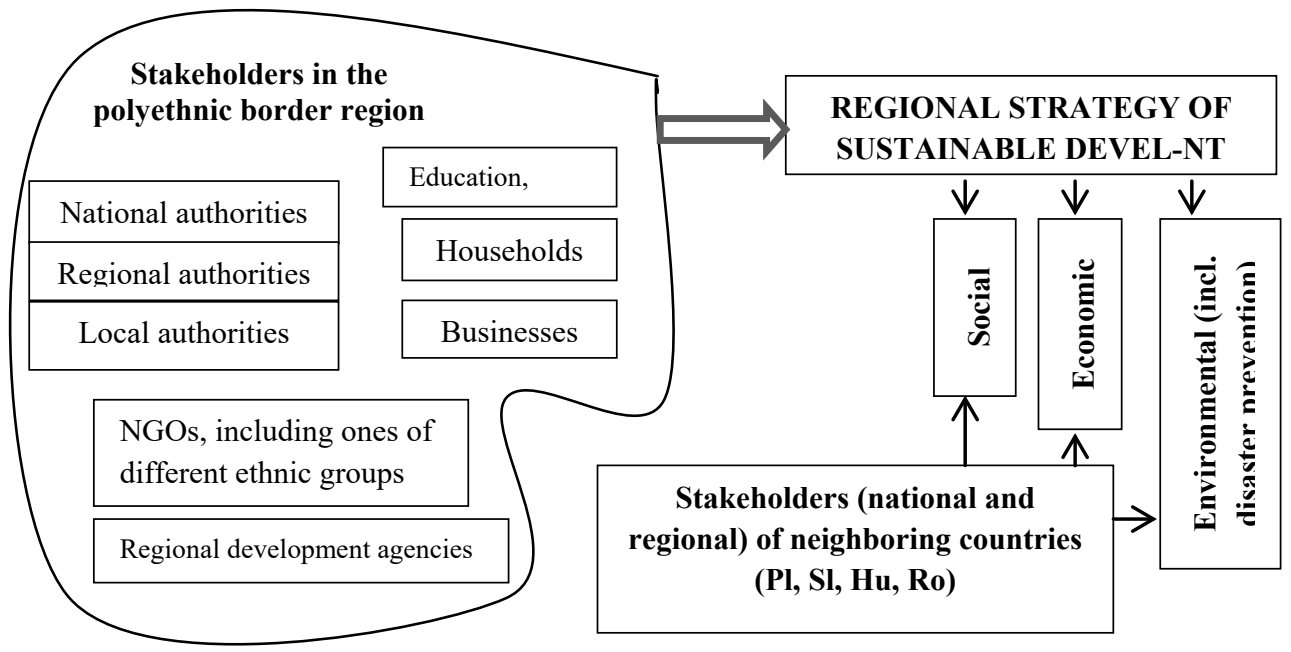

Fig. 1. Stakeholders and directions of sustainable development in polyethnic region (on the example of Transcarpathia).

The elaboration and implementation of effective sustainable development strategies is impossible without the establishment of effective partnerships between governments, businesses, various groups of people, and civil society institutions at the local, regional and national levels. The cooperation with neighboring countries is especially important for border regions in solving common sustainable development goals for adjacent territories, in particular in the field of environmental protection.

Elaboration of regional and local development strategies builds the understanding of the direction of movement, the basis for working out long-term and short-term goals, effective usage of resources and further promotion of public initiatives to minimize disparities in economic and social development, taking into account the needs of different ethnic groups in the region. Civil society is outside the scope of state power, it is not subject to direct state regulation and it reflects the current interests of different groups of population. Through the institutions of civil society (non-governmental organizations, associations, unions) different groups are structured, interact, express their social, economic, cultural, educational, linguistic interests and can influence the decision making on important issues. 
The activity of national minorities NGOs in Transcarpathia contributes to the harmonization of interethnic relations, revival and development of their languages, customs, traditions, cultural and artistic heritage. These NGOs also participate in cross border cooperation and solving tasks of social and economic development and environmental protection in the region.

Regional NGOs have rich experience, special knowledge and professional skills in the implementation of socially oriented and environmentally safe sustainable development programs. They are active initiators of cross-border cooperation projects in various sustainable development areas aimed to address common social, economic and environmental interests of neighboring communities, and mutual exchange of experience. Therefore, their experience is an extremely important asset in the elaboration and implementation of sustainable development programs.

The survey was compiled to find out the opinion of representatives of regional NGOs involved in the development and implementation of cross-border sustainable development projects. It was aimed to study the present status and opportunities for activating sustainable development in polyethnic regions.

The survey was conducted by the authors during summer and autumn of 2018. The representatives of 15 focus institutions (including Transcarpathia regional branch of the Association of Cities of Ukraine, Regional Development Agency of Transcarpathia, NGO "Carpathian Foundation", International Association of Institutions for Regional Development IAIRD, Center for European integration and national minorities, Transcarpathian enterprises support fund TES-Fund) were interviewed by face-to-face method. Questionnaire contained open-ended questions and respondents had the opportunity to choose several answers, therefore the total result may exceed $100 \%$.

Distribution of answers to the question about the priorities identified in the National Report "Sustainable Development Goals: Ukraine" (2017) for the region under study are shown in Table 1 (five levels of importance were identified, where 5 - very important, 1 not important at all).

Table 1. The distribution of answers to the question about sustainable development priorities for Transcarpathia as a polyethnic region, \% (priority 1 is not important at all, priority 5 is very important).

\begin{tabular}{|c|c|c|c|c|c|}
\hline \multirow[t]{2}{*}{ Sustainable development goals } & \multicolumn{5}{|c|}{ Priority } \\
\hline & 1 & 2 & 3 & 4 & 5 \\
\hline 1. No Poverty & 7 & 13 & 13 & & 40 \\
\hline Zero Hunger & 53 & 40 & & & \\
\hline Good Health and Well-Being & & & 67 & 13 & 7 \\
\hline Quality Education & & & 7 & & 87 \\
\hline Gender Equality & & 67 & 7 & & \\
\hline Clean Water and Sanitation & & 7 & 7 & 40 & 47 \\
\hline Affordable and Clean Energy & & & 40 & 47 & 7 \\
\hline Decent Work and Economic Growth & & & 7 & 20 & 80 \\
\hline 9. Industry, Innovation and Infrastructure & & & 13 & 40 & 40 \\
\hline 10. $\quad$ Reduced Inequality & & 53 & & 20 & \\
\hline 11. Sustainable Cities and Communities & & & 7 & 53 & 47 \\
\hline 12. Responsible Consumption and Production & & & 13 & 40 & 7 \\
\hline 13. Climate Action & 47 & 7 & 13 & 7 & 7 \\
\hline 14. Life Below Water & 80 & & & & \\
\hline 15. Life on Land & 40 & 7 & 13 & 40 & \\
\hline 16. Peace and Justice Strong Institutions & & 40 & 13 & & 47 \\
\hline 17. Partnerships to Achieve the Goal & & 7 & 47 & 13 & 13 \\
\hline
\end{tabular}

Source: compiled by the authors basing on the results of the survey 
Therefore, the most important priorities of sustainable growing in multinational Transcarpathia are identified as "Quality Education", "Decent Work and Economic Growth", "Sustainable Development of Cities and Communities".

Respondents gave the next replies to question "Which tasks for sustainable development are the most appropriate for the further development in Transcarpathia, considering its multinational character" (proposed to choose up to 5 answers):

- "Quality Education" (87\%),

- "Decent Work and Economic Growth" (67\%),

- "Sustainable Cities and Communities" (67\%),

- "Industry, Innovation and Infrastructure" (47\%),

- Three SD goals received 40\% each: "Clean Water and Sanitation", "Responsible Consumption and Production", "Partnership to Achieve the Goal".

Sustainable development tasks like "Zero Hunger", "Life on Land", "Climate Action" and "Life Below Water" were identified as the least appropriate for the region.

Respondents had option to suggest own answers to all questions of the survey. They additionally stressed that polyethnicity should be taken into account as one of basic components in all regional development projects. They also indicated security provision and speed-up systemic reforms, especially decentralization as important issues.

Respondents assumed that from the institutional point of view, sustainable development activation in a polyethnic region should be provided primarily by local governments (communities) (53\%), civil society institutions (47\%) and regional development agencies $(47 \%)$.

NGOs representatives identified the main problems of ensuring sustainable development in polyethnic region as following:

- non-transparency in assignment and distribution of public funding for development $(87 \%)$;

- weak cooperation between different partners in the elaboration of development projects $(67 \%)$;

- lack of state support for balanced regional growth programs on polyethnic issues $(53 \%)$.

Corruption, incomplete information and incompetence of national authorities regarding the polyethnic specifics in region were identified also as a problem.

Preservation and interpenetration of ecological, religious and cultural traditions of various nationalities of polyethnic regions can become the basis for balanced regional growth.

It should be noted that the region is actively using the privileges of its location. Regional participants attracted about 15.5 million euros during the period 2010-2015 through the participation in joint cross-border cooperation projects aimed to finance social, economic and environmental programs [14, p. 221].

Cooperation between border regions in resolving urgent common issues is constantly intensifying. For example, within the Hu-Sl-Ro-Ua ENI CBC Programme (priority disaster prevention) seven international projects for the total amount of 8,5 million euros are being implemented in the region as of the beginning of 2021 [15].

Problematic sustainable development issues in the polyethnic region are identified as following:

- weak coherence between sustainable development programs in border regions of neighboring countries, especially in environmental issues;

- contradictions between domestic societal policy and neighboring states' programs for humanitarian and cultural support of ethnic groups;

- uneven social and economic indicators of neighboring polyethnic regions, which lead to outflow of human resources to more developed regions. 
The main aspects of regional policy aimed to ensure a balanced growth of polyethnic regions are:

- comprehensive support of the evolution of cultural diversity of ethnic and religious groups, their active involvement in social processes;

- promoting the development of the national education system taking into account changes in all spheres of public life and respect for the linguistic rights of different ethnic groups;

- creation of favorable conditions for the development of cultural industries (book publishing, film production, support of cultural institutions), support of the network of museums for the actualization of historical and cultural heritage in the region;

- preservation and development of traditional ways of conducting certain types of economic activity of different ethnic groups (sheep breeding, winemaking, wickerwork) and their promotion on regional and international markets;

- further evolution of cross-border cooperation to exchange the best practices regarding self-government in cross-border areas.

\section{Conclusions}

The research of theoretical and methodological approaches showed the expansion and enrichment of sustainable development idea in the global context, which is associated with current trends in global economic, social, demographic, industrial, scientific and environmental trends, and global crises. Nowadays the concept of sustainable development is the basis for elaborating growth programs and strategies at all levels (global, national, regional, local and individual institutions).

Only the incorporation of all stakeholders (governments, businesses, households, education and R\&D, regional development agencies, NGOs, including NGOs of different ethnic groups) into elaboration and realization of sustainable development strategies allows to work out an effective long-term successful development trends. Results of the survey of regional NGOs representatives shows that activation of sustainable development in a polyethnic region should be driven by local governments (communities), regional development agencies, NGOs.

Execution of sustainable development tasks in border polyethnic regions should also include broad cooperation between domestic participants and partners of neighboring countries. Activation of cross-border cooperation allows to work out tasks to prevent and overcome consequences of mutual environmental problems.

It is necessary to support permanent informational and educational activities in localities of compact residence of various ethnic groups and to intensify dialogue between them and regional and local authorities, including the creation of advisory bodies for further involvement of different ethnic groups into the completion of certain sustainable development programs in the region, especially in bordering localities.

In traditionally multinational regions, question of multi-ethnicity should be taken into consideration during elaboration and realization of long-term strategies at all government levels to meet the needs of all involved participants.

\section{References}

1. World Commission on Environment and Development. (1987). Our Common Future. United Nations. https://sustainabledevelopment.un.org/content/documents/5987ourcommon-future.pdf 
2. Kahn, M. (1995). Concepts, definitions, and key issues in sustainable development: the outlook for the future. Sustainable development, 3(2), 63-69. https://doi.org/10.1002/sd.3460030203

3. Shi, L., Han, L., Yang, F., \& Gao, L. (2019) The Evolution of Sustainable Development Theory: Types, Goals, and Research Prospects. Sustainability, 11(24), 7158. https://doi.org/10.3390/su11247158

4. Bina, O. (2013).The green economy and sustainable development: an uneasy balance? Environment and Planning C: Government and Policy, vol. 31, 1023 - 1047. https://doi.org/10.1068/c1310j

5. Elliott, J. A. (2013). An Introduction to Sustainable Development (4th ed.). Routledge.

6. United Nations. The Millennium Development Goals Report 2015. United Nations.

7. Department for Environment, Food and Rural Affairs. (2005). Securing the Future: Delivering the UK Government Sustainable Development Strategy. The UK Government.

8. Paton, B. (ed.). (2012). National paradigm of sustainable development of Ukraine. Public Institution «Institute of Environmental Economics and Sustainable Development of the National Academy of Sciences of Ukraine». http://ecos.kiev.ua

9. Carpathian Project. Conservation and sustainable development of the Carpathians. (2006). http://www.dobrobut-hromad.org

10. Ministry of Economic Development and Trade of Ukraine. Sustainable Development Goals: Ukraine. (2017). Government of Ukraine. https://menr.gov.ua

11. Shevchenko, H., Petrushenko, M., Burkynskyi, B., \& Khumarova, N. (2021). SDGs and the ability to manage change within the European green deal: The case of Ukraine. Problems and Perspectives in Management, 19(1), 53-67. https://doi.org/10.21511/ppm.19(1).2021.05

12. Miklovda, V. P., Pitiulych, M. I., Hoblyk, V.V., Pityulych, M.M., \& Keretsman, N. I. (2020). Socio-Economic Transformations of Small Rural Settlements of Zakarpattia Amidst Decentralisation. International Journal of Criminology and Sociology, 9, 30893094. https://doi.org/10.6000/1929-4409.2020.09.375

13. Koval, V. (2011). "Polyethnicity" and "public administration": theoretical substantiation of the relationship of concepts. Bulletin of the National Academy of Public Administration, 1, 271-279.

14. Libanova, E. (ed.). (2019). Economic efficiency vs social justice: priorities of Ukraine's development at the stage of overcoming the crisis. National Academy of Science of Ukraine. Section of Social and Humanitarian Science.

15. Hungary - Slovakia - Romania - Ukraine ENI Cross-border Cooperation Programme 2014 - 2020 (2020). Financed Projects database. ENI Cross-border Cooperation Programme 2014 - 2020. https://huskroua-cbc.eu/projects 